\title{
Guarantee of the Right to Freedom of Speech in Japan-A Comparison with Doctrines in Germany
}

\author{
Takashi Jitsuhara
}

\section{Introduction: The 2016 World Press Freedom Index}

In the Reporters Without Borders' (RWB) 2016 World Press Freedom Index (WPFI), Japan was ranked 72nd. ${ }^{1}$ This ranking is next to Tanzania at 71 st and South Korea at 70th, and follows Lesotho at 73rd and Armenia at 74th. With regard to the changes in the ranking, Japan was ranked 11th in 2010, and 61st in 2015, which means, "72nd" reflects a downward trend for the Japanese ranking. ${ }^{2}$ RWB references the "Act on the Protection of Specially Designated Secrets" (APSDS) as the reason for the drop, and has expressed concerns that many matters - such as the Fukushima nuclear disaster-will be classified as state secrets.

This article deals with the right to freedom of speech as a "human rights issue in Japan." Moreover, it is discussed with regard to the guarantee of freedom of speech not only in recent years, but also formerly, taking note of legal matters that include concrete laws, decisions, and theories. While Japanese theories are influenced by arguments pertinent to freedom of speech in the United States, it will be mentioned that this effect is limited to precedents in the Japanese courts. After discussing the protection of and restrictions on that freedom, I examine some cases and opinions in Germany, which exemplify one country other than the United States, in order to adopt a comparative approach to the study of constitutional law. ${ }^{3}$

\footnotetext{
${ }^{1}$ https://rsf.org/en/ranking (accessed February 17, 2017).

${ }^{2}$ It was 37 th in 2005 .

${ }^{3}$ As a prior research, Suzuki (2016b), p. 106.

T. Jitsuhara ( $\square)$

Faculty of Law, Fukuoka University, Fukuoka, Japan

e-mail: jitsuhara@fukuoka-u.ac.jp 


\section{Freedom of Speech in Japan}

The first objective of this paper is to examine Japanese circumstances as they pertain to the guarantee of freedom of reporting. In Japanese constitutional law (the Constitution), Article 21 is the provision most closely related to that freedom. This article points to such concepts as assembly, association, speech, and a free press, and covers all other forms of expression. Although it does not make explicit reference to freedom of reporting, freedom of reporting is thought by constitutional authors, and according to precedent, to be desirable for protection under Article 21. For example, in the 1969 Hakata Railway Station case, ${ }^{4}$ the Japanese Supreme Court (the Court) said that freedom of reporting came under the guarantee of Article 21 of the Constitution, and freedom of research was also sufficiently reflected in the spirit of Article 21.

Arguments regarding the limits on freedom of reporting or speech are discussed next. Though legal restraints are the main constraints on freedom of speech, "unofficial regulations" are also important factors in Japan.

\subsection{Legal Restraints}

There are many restrictive acts or articles in Japanese law. Because of the reference made to recent legislation by RWB in relation to Japan's 2016 WPFI ranking, I will deal with recent legal topics.

First, there is the Broadcast Act, which regulates freedom of reporting. Article 3 requires respect for the independence of companies' program broadcasts, but Article 4, Section 1, provides for "editing rules" that note some guidelines for the contents of a broadcast. This article requires that TV programs do not harm public safety or morals, are politically fair, do not distort the facts, and clarify the points at issue from as many perspectives as possible, where there are conflicting opinions on the subject. ${ }^{5}$ On the other hand, because no article exists under the Broadcast Act relating to sanctions when violations occur, the legal aspects of the editing rules are a controversial matter. ${ }^{6}$ Japanese scholars maintain that the editing rules impose only a moral obligation on broadcasting companies, and even if a company violates the editing rules, the media themselves are responsible for deciding whether a violation has occurred, and, if so, how they should respond to it. In contrast, the Ministry of Internal Affairs and Communications (MIAC), as the competent ministry for broadcasting, has often provided "administrative guidance" in the case of

\footnotetext{
${ }^{4}$ The Supreme Court Decision, Grand Bench, November 26, 1969, Keishu 23-11-1490.

${ }^{5}$ There is not such a direct legal regulation on the contents of papers or articles of the print media.

${ }^{6}$ Suzuki and Yamada (2011), p. 157 (Shoichiro Nishido).
} 
violations of the editing rules, ${ }^{7}$ and considers such violations as possible grounds for suspension of the operation of a broadcasting signal under the Radio Act.

Recently, other controversies have arisen about how the editing rules were interpreted on the occasion of a comment made in the House of Representatives in 2016 by the Minister of the MIAC, Sanae Takaichi. Ms. Takaichi stated that the broadcasting signal might be suspended in the case of violations of political fairness as stipulated in the editing rules. A dispute followed the issuance of this viewpoint, which clarified that there was the possibility of a broadcasting signal being suspended based on violations of the editing rules even in (only) "one" broadcast program. ${ }^{8}$

Furthermore, with regard to the APSDS, as will be explained later, although laws have been passed that protect the secrets held by national public officers, the APSDS is the first act to generally protect government secrets in Japan. This statute raises various issues, such as the lack of a reliable system to end the designations, or the unclear range of specially designated secrets. In addition, Article 25 stipulates punishments for conspiring, inducing, and inciting activities that involve the disclosure of one of the above-mentioned "secrets," despite Article 22, Section 1, which requires respect for "the freedom of news reporting or news coverage, which contributes to guaranteeing the citizens' right to know."

To this point, the recent acts and topics concerning freedom of reporting or speech have been described. This might imply that infringements on freedom of reporting are only temporary. Therefore, the disputes that were formerly raised over the freedom of speech guarantee are discussed next.

Firstly, regulations on obscene materials are established in ordinary law. Article 175 of the Penal Code regulates obscene documents, drawings, and data (subsequently referred to as the "materials"), and provides punishments for their distribution, sale, and display in public, or dissemination. Moreover, Section 2 provides criminal penalties for those who possess or store the already-noted materials for the purpose of sale. This article, however, in describing the regulated materials exclusively as "obscene," lacks any additional information. That is, Article 175 of the Penal Code triggers issues related to lack of clarity and breadth. In addition, the Customs Act prohibits the importation of books that are "detrimental to public security or corrupt public morals." However, this concerns freedom of speech as the right to receive information from foreign books in Japan. Moreover, in local ordinances, there are statutes that regulate "harmful books"-books that are obscene, cruel, or promote crime (ordinances regarding "the Healthy Development

\footnotetext{
${ }^{7}$ Recent "administrative guidances" in the name of the Minister: Against Kansai Broadcasting in 2007 and NHK in 2015.

${ }^{8} 10$ min of the 190th Budget Committee of the House of Representatives, February 9, 2016, p. 4. If so, the editing rules could be unconstitutional. Suzuki (2016a), p. 24 writes that, "unless editing rules are interpreted as ethical codes, it is difficult to permit its constitutionality".

${ }^{9}$ There is also the "Security Clearance Assessment," which is to assess people who are going to deal with the specially designated secrets. Its deep invasion into privacy could lead to a violation of privacy.
} 
of Youths," referred to hereafter as "OHDY")—and the sale and means of sale. Concerning OHDY, the lack of clarity and the breadth of local ordinances should be questioned similarly to the provisions under the Penal Code and the Customs Act.

Beyond the prohibitions of obscene materials, articles under the Public Offices Election Act (POEA) regulate campaigns in elections. This statute stringently regulates election campaigns. As a typical restriction, Article 138, Section 1 provides for an across-the-board ban on canvassing door to door. Also, the POEA has articles that strictly regulate the display of election documents. ${ }^{10}$ These controls serve to illustrate some problems involving the role of constitutional law, because election campaigns are an example of typical political speech.

In addition, the National Public Service Act (NPSA) might also have the effect of placing a restriction on reporting or speech. Article 100 punishes a national public officer for leaking government secrets, and Article 111 specifies punishments for persons who "instigate" government officers to divulge secrets. Because of its power to penalize journalists who ask a national public officer to provide information, this article has provoked controversy over its constitutional validity with regard to the collection of information as a precursor to preparing reports. Meanwhile, Article 102 of the NPSA bans government officers from political activities provided by the National Personnel Authority. That article plainly refers to "political activity," which, however, might also involve political speech, and, in addition, the NPSA has the further problem of delegating the definition of prohibited acts to an administrative agency.

\subsection{Unofficial "Regulations" and Issues Concerning "Self-restraint" for the Media}

Up to now, observations have shown that Japanese legal restraints and related topics are not just temporary issues, but existed formerly. In Japan, in addition to such legal restraints, there are also unofficial "regulations," described as "self-restraint." For instance, a recent topic that has drawn attention is described as insufficient reporting of the Fukushima nuclear disaster. Since there is no law prohibiting reports about a nuclear disaster, such matters can be categorized as unofficial regulations.

Furthermore, there are problems with the NHK. This is a public broadcasting company with a board of governors. This board has the authority to pass resolutions on matters provided in law. Each member is appointed by the Prime Minister, with the consent of both Houses of the National Diet (Article 31 of the Broadcast Act). When the NHK was given the role of a public broadcasting company, such controls

\footnotetext{
${ }^{10}$ Accordingly, in Japanese election campaigns, it is usual for candidates to use cars to advertise their names. Such a strange style was illustrated in the film "Campaign" (Director: Kazuhiro Soda, 2007).
} 
by the political sector might have been necessary. The NHK, however, also enjoys freedom of reporting, and, therefore, must not yield to the national government in this regard. ${ }^{11}$ Nonetheless, because of some recent appointments of members closely related to the Prime Minister, it is feared that such management might have an influence on the content of the station's TV programs. In addition, the board can appoint the President of the NHK (Articles 51 and 52 of the Broadcast Act). Until January 24, 2017, its President was Mr. Katsuto Momii. However, he made some controversial remarks during his tenure. For example, it was reported that he referenced an international program with regard to territorial issues when he attended a press conference announcing his appointment as President in 2014. According to the media, he said, "we should not say 'left' when the national government says "right." "12 In other news his recent comments on a Disaster Recovery Meeting of the NHK were conveyed. The news noted his desire to report based on governmental official announcements about issues concerning nuclear power plants. ${ }^{13}$ Such remarks might reflect NHK's lack of independence from government intentions.

Another issue concerned relations between broadcasting and government. This was a dispute over a comment by, and the behavior of, Prime Minister Shinzo Abe, when he appeared on the news program of a commercial TV station. This program showed scenes and comments from its interview with various citizens, and most of these comments were skeptical of the current government's economic policies. Mr. Abe complained that only critical comments had been conveyed intentionally. However, his claims were criticized as a form of pressure on broadcasting companies. Furthermore, the Liberal Democratic Party of Japan (LDP), as the ruling party, sent each broadcast company a paper requiring "fair and neutral" broadcasting reports in the 2014 general election for the House of Representatives (Shugiin). Although such a statement has no binding power on the media, it raises the fear that government pressure may have some effect on the media. The issue of pressure $^{14}$ caused by governmental desires was also mentioned by the Committee for the Investigation of Broadcasting Ethics, which criticized the intervention of a department in the LDP on the NHK in an investigation of a TV program. ${ }^{15}$

The effects of recent unofficial regulations and self-restraint by the media outlined above might create the impression that these effects have occurred only recently. However, such issues have been evident in Japan for some time.

An issue alluded to above was the customary practice under the Newspaper Act before World War II, in which newspaper companies had to give the Ministry of the Interior a copy of their newspapers at the time of publication, after which the

\footnotetext{
${ }^{11}$ Suzuki and Yamada, supra note 6, p. 159 (George Shishido).

${ }^{12}$ The Asahi-Shimbun, January 26, 2014 (Morning-Paper).

${ }^{13}$ The Asahi-Shimbun, April 24, 2016 (Morning-Paper).

${ }^{14}$ At the same time, in recent years, chiefs of reporting companies often dine privately with the Prime Minister, which leads to criticisms of their stances.

${ }^{15}$ Its 23 Opinion (November 6, 2015), p. 27.
} 
Ministry would approve its content or, if there was some problem, order that it not be sold or delivered. Although this rule was a kind of posterior restraint, there was a custom in the media to get the approval of the Ministry before publishing. Therefore, such a custom meant that the media themselves were engaging in "self-prior restraint." This information helps to explain how after the War the Court maintained that the regulation under the Newspaper Act was a "censor in substantial means in its operation."

Following Japan's defeat in the war, a "new" Constitution was enacted, which was intended to protect human rights, as well as freedom of speech, more strictly. Nonetheless, the media's self-restraint continued even in the postwar era. The matter of the "press club" being a problem has been mentioned. In Japan, press clubs have been set up in government offices, where members who are reporters are permitted, for example, to use the rooms in city halls to obtain information from administrative officers. On the one hand, setting up a press club might have significance as a kind of professional association, in order to strengthen its power to counter government pressure, but, on the other hand, such clubs might merely become organizations for promulgating governmental announcements. Since many Japanese journalists, as members of press clubs, rely on getting information from the office to which they belong, it is often noted that they avoid criticizing such government offices. ${ }^{17}$ In addition, there is also the issue of the variety of reporting agreements in Japan, in relation to press clubs. Such agreements are reached between each governmental office and the press club concerned, and mainly relate to the Imperial Household Agency or the police department in relation to kidnappings. The agreements involving kidnappings certainly have some relevance for safeguarding the lives or physical wellbeing of kidnapped persons, but it is a different case when a press agreement involves the Imperial House for the purpose of preventing a report about a person who might marry a member of the imperial family. Therefore, the appropriateness of reaching such agreements needs to be considered.

\subsection{Precedent in Japan Dealing with Freedom of Speech}

Following the discussion of how freedom of speech has been restricted, there should be some examination of how the Japanese courts have responded to these limits. First, however, a short explanation of the Japanese judicial system is provided.

\footnotetext{
${ }^{16}$ Customs Search: The Supreme Court Decision, Grand Bench, December 12, 1984, Minshu 38-12-1308.

${ }^{17}$ see Yamada (2010), p. 66.
} 
In Japan, there is no constitutional court, and the Supreme Court should also prove constitutionality. ${ }^{18}$ Therefore, Japanese judicial precedents and the dominant theoretical framework are regarded as an "incidental" system, and are thought to exist mainly to resolve concrete conflicts and decide on the possibility of providing a remedy that would satisfy the interests of the parties concerned. With regard to decisions made by Japanese courts, there have been some decisions that declared unconstitutional regulations as being unconstitutional, and in recent years, the Japanese Supreme Court has declared more statutes unconstitutional than before. ${ }^{19}$ Moreover, it has guaranteed expressions by adopting a restrictive interpretation of the provisions of an ordinary law. ${ }^{20}$

There has, however, been no judgement on the unconstitutionality of the violation of freedom of speech. As already mentioned, Article 175 of the Penal Code has been upheld as being constitutional, despite the controls on obscene materials. ${ }^{21}$ In 1957, the Court, in accordance with the definition of the word "obscene," pointed out such issues of public interest as "sexual order" and the maintenance of minimal sexual morals, to justify limits on freedom of speech. Despite a few modifications to the definition of "obscenity," the Court has been consistent in its interpretation of Article 175 of the Penal Code as not being unconstitutional. Moreover, the prohibition on the importation of obscene books has not been regarded as censorious or unconstitutional, because in their judgement, the judges said they were comfortable with protecting the public interest by maintaining and ensuring wholesome sexual morals for the nation. ${ }^{22}$ Furthermore, although the statement "books that are detrimental to public security or that corrupt public morals" is an abstract or broad one, the court has perceived it as strictly interpretable, and has stated that the meaning of this provision became clear after taking account of the precedents dealing with Article 175 of the Penal Code. In addition, in testing the correspondence on the materials prohibited from being imported, the Court understood the prohibition to be incidental to the customs-collecting procedure, and it did not regulate the content itself. Although in a later case the prohibition on importing a photography book was rejected by the Court, ${ }^{23}$ it has continued to hold that the importation prohibition under the Customs Act is not unconstitutional. Furthermore, the OHDY was also justified as satisfying the constitution, even when it regulates the harmful books. ${ }^{24}$

Apart from obscene materials, prohibitions under the POEA have also been allowed under constitutional law, even when it concerns canvassing door to door.

\footnotetext{
${ }^{18}$ Japanese constitutional interpretations also permit the lower courts to judge constitutionality.

${ }^{19}$ see Tonami (2015), p. 6.

${ }^{20}$ see Horikoshi: the Supreme Court Judgement, Second Pretty Bench, December 7, 2012, Keishu 66-12-1337.

${ }^{21}$ The Supreme Court Judgement, Grand Bench, March 13, 1957, Keishu 11-3-997.

${ }^{22}$ The Supreme Court, supra note 16.

${ }^{23}$ The Supreme Court Judgement, Third Pretty Bench, February 19, 2008, Minshu 62-2-445.

${ }^{24}$ The Supreme Court Judgement, Third Pretty Bench, September 19, 1989, Keishu 43-8-785.
} 
In one case, the Court reasoned that these kinds of election campaigns should be prevented, because they provoked such harmful effects as corruption and disturbance on the calm lives of the voters. ${ }^{25}$ With regard to the issue of punishment for breaches, in other cases, while the Court has certainly recognized the significance of freedom of research, it has pointed to the moral problems concerning research activities in that case, and endorsed the conviction of a journalist as not being unconstitutional. $^{26}$ There is also a case involving the punishment of a public officer with the national postal service for displaying election documents when not on duty. ${ }^{27}$ The Court regarded this act as political activity prohibited under the NPSA, and in its decision, considered the purposes of the prohibitions of certain kinds of political activities, before deciding there was a balance to be struck between the merits and the demerits arising from such prohibitions. As a result, the Court upheld the conviction. According to that judgement, such regulations are indirect and incidental infringements on activities that could engender fear, and damage the political neutrality of public officers.

Japanese judicial practice, thus, has the characteristic tendency of using the balancing test for freedom of speech. ${ }^{28}$ Furthermore, the Court has also categorized the regulations for freedom of speech into direct and indirect ones.

\subsection{Conclusions-Guarantee of Freedom of Speech in Japan}

Circumstances concerning freedom of speech have been discussed. It has been made clear that in Japan, although freedoms of reporting and speech enjoy constitutional protections, these freedoms are also governed by regulations in ordinary law. On the other hand, the Court has maintained the stance of declaring constitutional regulations on freedom of speech. Certainly, the legal restraints on freedom of speech allowed have not been unlimited, but a balancing test has often been applied, so that many regulations have come to be justified by the Court. Furthermore, in Japan, there exists the media's self-restraint and other disturbing effects that would be difficult to legislate for in any judicial review.

The Japanese ranking in the WPFI has been decreasing dramatically since 2011. However, the legal and unofficial regulations on freedom of speech are found to have existed much earlier. Therefore, limitations on the guarantee of freedom of

\footnotetext{
${ }^{25}$ The Supreme Court Judgement, Third Pretty Bench, July 21, 1981, Keishu 35-5-568.

${ }^{26}$ Reporter Nishiyama: The Supreme Court Judgement, First Pretty Bench, May 31, 1978, Keishu 32-3-457. In this case, it was regarded as problematic that the journalist and the national public officer were committing "adultery."

${ }^{27}$ Sarufutsu: the Supreme Court Judgement, Grand Bench, November 6, 1974, Keishu 28-9-393.

${ }^{28}$ Concerning recent more precise testing, see Watanabe et al. (2016), p. 228 (Gerorge Shishido).
} 
reporting or speech are not only a temporary problem, but have been an important matter of fundamental rights for some time.

\section{Doctrines in Japan Relating to Freedom of Speech}

Having described the current situation in Japan with regard to its statutes, precedents, and the media, the issue to turn to now is how constitutional lawyers have responded to them.

Even though the Court has not declared the regulations on freedom of speech to be unconstitutional, the absence of any decision declaring unconstitutionality might reflect the high quality of the statutes limiting freedom of speech. As has already been said, however, the Japanese provisions are problematic in that they are both vague and broad. Therefore it is difficult to state unequivocally that the lack of decisions declaring the statutes unconstitutional is due to their high quality.

Japanese constitutional lawyers remain critical of the Court's tendency to use a balancing test so laxly, when considering the constitutionality of the limits on freedom of speech. The Court's conclusions crystallize its difficulties when attempting to emphasize abstract interests to justify the restrictions on freedom of speech, or to fail to suggest a standard for weighing competing values. ${ }^{29}$ Moreover, although scholars do not inherently reject the practice of balancing itself, they require that the Court give freedom of speech "dominant status." A standard Japanese textbook on the Constitution holds that it is necessary to distinguish between mental freedom infringements and other types of infringements, and it notes that constitutionality should be stringently tested if mental freedom is limited. ${ }^{30}$ Its text describes freedom of speech as important for developing personality and democracy in constitutional rights. This concept is called the "two-tier test" doctrine.

The two-tier test distinguishes between regulated mental freedoms and other regulated freedoms. At the same time, there are a variety of regulations on freedom of speech. As a result, Japanese constitutional scholars distinguish between restrictions on freedom of speech that are content-based, and those that are content-neutral. They argue that constitutionality should be reviewed more stringently, especially with regard to clarity, or at a minimum when this freedom is regulated according to its content. In contrast, the constitutionality of content-neutral regulations might prove to be a little more tolerant ("the middle test"). Content-neutral regulations consist of regulations that designate times, places, or modes, and impose controls on "symbolic speech." 31 Moreover,

\footnotetext{
${ }^{29}$ Yamakawa (1987 (2012)), p. 323.

${ }^{30}$ Ashibe (Takahashi) (2015), p. 103.

${ }^{31}$ Ibid., p. 196 defines the term "symbolic speech" as "conduct expressing a thought and an assertion thorough some actions," and mentioned, as an example, such conduct as to publicly burn one's draft card for a war. Fallon (2013), p. 54- calls that conduct "expressive conduct."
} 
constitutional theorists also distinguish between prior and posterior restraints, of which the former are regarded as riskier. In addition, many ${ }^{32}$ observers hold that the role of censor should be absolutely prohibited. ${ }^{33}$

Japanese scholars, thus, regard mental freedom as being especially important and requiring very restrictive reviews of its constitutionality. These concepts have been influenced by arguments in the United Sates, where, for example, because "actual malice" is required when a conviction is based on defamatory statements made against a public official, such statements are only seldom considered to be illegal. ${ }^{34}$ Furthermore, the Japanese Constitution is strongly influenced by the United States, and both countries have similar judicial systems, which might explain the strong influence American theories have had on Japanese academics.

However, circumstances in Japan are different from those in the United States. Firstly, the background to the discussion about the prior status of freedom of speech in the United States is that regulations on economic freedom have often been rejected as being unconstitutional. In Carolene Products in 1938, the US Supreme Court (the Supreme Court) implied the two-tier test. ${ }^{35}$ In this decision, the Supreme Court, upheld that the challenged regulation on the economic activity was constitutional, while indicating strict reviews for cases of legislatorial regulation of political procedures (its Footnote 4). Japanese arguments on the two-tier test emerged from criticisms of the Japanese Supreme Court too easily justifying the restrictions on freedom of speech based on the public interest. Moreover, the balancing test is understood in the United Sates to be tolerant of the constitutionality of regulations, but in Japan, that test began to be asserted with the claim that regulations on freedom of speech should not be easily justified. Although for some time after World War II the Court said the public interest was sufficient to justify restrictions on freedom of speech, a balancing test was later introduced to more strictly consider the constitutional issues raised. ${ }^{36}$

\section{Comparison with German Doctrines}

In Japan, the two-tier test has been developed against the background of a critical view being taken of the Court for not sufficiently safeguarding freedom of speech, and with reference to the observation that many theories refer to American theories. There are certainly differences between both countries in how they have begun to use the two-tier test and the balancing test. Indeed, when the Japanese Supreme

\footnotetext{
${ }^{32}$ Ibid., p. 198 regards it not so.

${ }^{33}$ Sato (2011), p. 257. The Supreme Court also understands that the word censor means absolutely prohibited (supra note 16), despite different definitions between jurisprudence and scholars.

${ }^{34}$ New York Times Co. v. Sullivan (1964).

${ }^{35}$ United States v. Carolene Products Co. (1938).

${ }^{36}$ see Yamakawa, supra note 29, p. 343.
} 
Court justifies the regulations on freedom of speech, it seems to be a good alternative to commit to the theories in the United States, where strict protections have been established for freedom of speech.

The Japanese Supreme Court, however, has taken a different stance on various issues. The Court has never declared the unconstitutionality of a regulation on freedom of speech. That situation might lead one to ask whether it is also appropriate to refer to doctrines in countries other than the United States, such as, for example, Germany. In fact, many Japanese lawyers refer to German disputes, but they have also been criticized.

\subsection{Skeptical Views of German Protection of Freedom of Speech}

Firstly, as a matter to be attended to when we introduce a German issue to Japan to review its constitutionality, Professor Tetsuharu Matsumoto ${ }^{37}$ notes that in Germany the idea of applying a strict test to the regulations on freely expressing opinions has not been adopted. According to him, there are differences between the thinking in Germany and the United States, since the US Supreme Court has applied a test mainly based on the First Amendment, and judicial reviews are incidental and concrete. In contrast, in Germany, he mentions how, when a review is conducted, it involves human dignity at its core, and, furthermore, the Constitutional Court can also conduct an abstract review.

After adding that he does not have details of Germany's in-depth discussions, Professor Matsumoto speculates that it is difficult under the German approach to describe freedom of speech as a dominant material value, because the concept of human dignity is at its core. In his view, whereas dealing with the conflicts between judicial reviews and democracy has been an issue in the United States, it might not arise in Germany, based on the Constitutional Court's competence in dealing with abstract reviews. The result of that conclusion for him is that, "it might be difficult for the thought to arise that the courts should strictly review freedom of speech, when democracy is accepted as legitimate."

However, his observation is likely to require two considerations. The first question is whether, in Germany, a conflict did not arise between judicial reviews and democracy. ${ }^{38}$ The other question, dealt with in this article, is whether there exists a German view on applying a strict test to regulations on the right to freely express opinions. With regard to this question, Professor Matsumoto refers to the views of Professor Shigenori Matsui, which are presented next.

Professor Matsui says that there is no one approach to applying different tests to each aspect of fundamental human rights in Germany, and he asserts that the

\footnotetext{
${ }^{37}$ Sogabe et al. (2012), p. 20 (Tetsuharu Matsumoto).

${ }^{38}$ Jitsuhara (2013).
} 
two-tier test does not exist there. ${ }^{39}$ In his view, although there is also a distinction in Germany between fundamental rights related to, and not related to, human dignity, such a concept does not result in the view that a strict test should be used to assess limitations on freedom of speech.

He also discusses the problems arising from discussions about freedom of the press. ${ }^{40}$ According to him, the mass media might be required to take some responsibility for the circumstances related to its social power-a concept that is discussed in Germany under the rubric of "public responsibility" or "public mission." In Germany, the "public mission" of the press is provided for by the press ordinance of each state. As he notes, responsibilities of the press in Germany include registering the collection or supply of information and participating in opinion-building. In contrast, he observes that the German approach, already cited, must trigger serious constitutional questions concerning freedom of speech, and in particular, such problems as a public mission being the media's legal duty, the establishment of legal institutes to test the media's fulfillment of its responsibilities, and its attempts to realize and ensure its responsibilities through legislation.

Professors Matsumoto and Matsui, thus, argue that the German guarantee of freedom of speech reveals problems when viewed from a Japanese perspective. Moreover, Professor Matsui seems to think that there are similar problems with regard to the guarantee of freedom of the press. For them, the question is, firstly, whether fundamental rights in Germany are distinguished exclusively by their relationship to human dignity, and especially whether freedom of speech is not regarded as being related to values other than human dignity. Secondly, it should be asked whether the Federal Constitutional Court of Germany (the Constitutional Court), or German constitutional scholars, think it necessary to rigorous assess constitutionality if freedom of speech is regulated. In Japan, many constitutional lawyers refer to the German approach to examine cases in which freedom of speech is strongly protected. ${ }^{41}$ In these cases, a third question arises as to whether Professor Matsui's opinion is really appropriate. His position on freedom of the press in Germany could lead to the impression that the German press is only weakly regulated by the state ordinances. However, it is necessary to show what these ordinances have realized or ensured, in their provision of a public mission as a legal responsibility for the media.

For this reason, considerations of its appropriateness require a description of the German situation. Questions related to how freedom of speech is protected and limited in Germany, how the Constitutional Court tests the constitutionality of regulations on freedom of speech, and how constitutional lawyers address them, are discussed next.

\footnotetext{
${ }^{39}$ Matsui (2010), p. 300.

${ }^{40}$ Matsui (2013), p. 347.

${ }^{41}$ Mouri (2008), p. 243.
} 


\subsection{Freedom of Speech in Germany}

First, with regard to protections of freedom of speech, the Basic Law for the Federal Republic of Germany (the Basic Law or the "Grundgesetz" is the constitutional law of Germany), on the one hand, guarantees freedom of communication. Article 5, Section 1, protects "the right to freely express opinions," and the second sentence provides for both freedom of the press, and freedom of reporting by broadcasting or films. ${ }^{42}$ On the other hand, Article 5, Section 2 of the Basic Law enumerates some grounds to permit regulations on freedom of communication. In addition to the expressly mentioned general laws (allemeine Gesetze) and human honor, the other constitutional interests are thought to provide the basis for limiting freedom of communication. $^{43}$

It is remarkable that there are provisions in Germany's ordinary laws that punish people who speak or act with the aim of justifying the former Nazi regime, as for example, in Article 86, Section 1, Number 4, and Article 130, Sections 3 and 4 of the Penal Code. Furthermore, most German states have a press ordinance with provisions that could be regarded as imposing restrictions on the freedom of the press. Despite differences in details, the public responsibilities, privileges, and duties of the press are mostly provided for. A typical example is the right to make a counterargument to factual assertions by the press. Article 4 of the Bayern Press Act also provides privileges for the media.

\subsection{German Decisions Concerning Freedom of Speech}

Thus, in Germany, limits on this freedom exist in ordinary law and local ordinances. The question is how the Constitutional Court considers the constitutionality of such legislative limits. Before moving to that discussion, the German judicial system should be described.

Unlike in Japan, there is a Constitutional Court in Germany. The authority to declare the unconstitutionality (invalidity) of legislation belongs exclusively to the Constitutional Court. For example, besides the well-known "Abstract Judicial Review of Statutes," the Constitutional Court also has the authority to conduct Constitutional Complaint proceedings that have some similarities to those procedures in Japan and the United States. The procedural mechanism for making Constitutional Complaints allows every person to apply directly to the Constitutional Court, which in turn deals with infringements on fundamental rights - not only through concrete legal orders, but also through judicial decisions of the

\footnotetext{
${ }^{42}$ It is different from the Japanese constitutional law for the German Basic Law to expressly provide freedom of reporting.

${ }^{43}$ Schulze-Fielitz (2013), p. 685.
} 
ordinary courts or the "law itself." 44 Among the procedures dealt with by the Constitutional Court, the Constitutional Complaint procedure has proven to be the most popular in a number of cases.

\subsubsection{About Freedom of Speech}

As already mentioned, the German penal code that punishes words and acts that support Nazi ideas seems to be well known. Such a regulation is a content-based restraint, and therefore, according to Japanese scholars, such a ban should be categorized as a matter to be strictly tested for its constitutionality.

One decision of the Constitutional Court concerning such speech occurred in the "Auschwitz lie" case. ${ }^{45}$ In this case, a conflict emerged when permission was granted for a neo-Nazi party to hold a symposium under the condition that it would not be denying the persecution of the Jews that occurred during the Third Reich period. The Constitutional Court accepted this administrative act to be constitutional.

The Constitutional Court has distinguished between the protected acts under Article 5, Section 1 of the Basic Law, considering them as opinion statements and factual assertions. On the one hand, opinion statements should be safeguarded, regardless of the contents, and those protections should cover different types of statements. On the other hand, the Constitutional Court has held that factual assertions, containing obviously untrue facts, lie outside the freedom to form opinions. It reasoned that such assertions could not contribute to the opinion-building assumed by the Basic Law. Accordingly, the Constitutional Court has firstly categorized as a factual assertion remarks that avow the absence of any persecution of Jews, and maintained that it had become clear in many fields that those assertions are evidently untrue. According to this decision, such an assertion does not constitute protection of the freedom of forming opinions.

At the same time, the assembly planned in this case intended to consider whether it could discuss the possibility that history after World War II has had the effect of "extorting" something from the German politic. The Constitutional Court held that expressions dealing with the "possibility of extortion" were the presumption for opinion-building, and regarded them to be constitutionally guaranteed under Article 5, Section 1, Sentence 1. But the interpretations of Article 185 of the Penal Code that stipulates punishments for insults, and Article 5, Number 4 of the Assembly Act, were held to be not questionable, and no constitutional problem was identified in this case, despite the challenges to restrictions on the freedom to freely express opinions. This decision argued that the honor of Jews who live in Germany should

\footnotetext{
${ }^{44}$ This procedure would be possible for a person who thinks that a law could be applied, and that such application could damage such a person.

${ }^{45}$ BVerfGE 90, 241.
} 
be protected because of their fates, and stated that therefore to deny the persecution of Jews should be regarded as defaming the honor of this group.

When the Auschwitz lie case, as a result, justified the restrictions based on the contents expressed, it might be possible to assume that, in Germany, it is easy to justify regulations on freedom of speech. However, the right to freely express opinions has been held to be important by such German judges as the one in the "Lüth” Decision.

"Lüth" Lüth is an important decision in Germany's postwar constitutional history. In this case, a Constitutional Complaint applicant called for a boycott of a film made by a scriptwriter who had made propaganda films under the Nazi regime. A film company applied to the ordinary court for an injunction against the applicant's request to boycott the film, and this injunction was granted. This decision was challenged through the Constitutional Complaint procedure, and the Constitutional Court refused the injunction.

It has, firstly, been said that the Basic Law formulates an objective order (objektive Ordnung). Despite there being conflicts between private persons, the Constitutional Court has argued that the system of fundamental rights is a value system (Wertssystem) that should be applied in all fields of law, and that it also has a "radiating effect" on the area of civil law. In this regard, the judgement noted that the Basic Law expects the regulations on the freedom to freely express opinions under general laws.

However, the Constitutional Court has maintained that the fundamental right to freely express opinions is just constitutive of liberal and democratic nations, and that freedom of expression should be a principle that is given priority in all legal fields. As suggested above, the Basic Law describes the right mentioned here, to be regulated by the general laws, but the Constitutional Court noted that such laws must be interpreted with respect to their value in a liberal and democratic nation, when the laws regulate fundamental rights, and their infringements need to be limited by the "radiating effects" of the right to freely express opinions (the "interaction theory:" Wechselwirkungstheorie). ${ }^{46}$

These statements in Lüth have been referred to repeatedly with regard to the importance of the freedom to freely express opinions within a liberal and democratic national order. This relates to the significance of the right to express opinions, for example, in the determination that concluded it was unconstitutional to prohibit the distribution of leaflets in Frankfurt Airport without prior permission. In this case, the Constitutional Court noted the freedom to freely express opinions that are of constitutive significance for the liberal and democratic order. ${ }^{47}$

\footnotetext{
${ }^{46}$ BVerfGE 7, $198<205-209>$. Jouanjan (2009), p. 876 explains that the "applicable general law may restrict the freedom of expression, while freedom of expression imposes a restrictive interpretation on the law itself."

${ }^{47}$ BVerfGE $128,226<266>$.
} 
Chilling Effects Attention needs to be paid to the judicial decisions in relation to the chilling effects of legal sanctions on the freedom to freely express opinions. For example, a conviction for defamation was held to be unconstitutional when leaflets described the past of a new leader of a local branch of the Christian Democratic Union (CDU) party in Germany. ${ }^{48}$ In this case, the Constitutional Court pointed to the problem of criminal penalties having "chilling effects" on the normal exercise of the freedom to freely express opinions. The judge said that such chilling effects were particularly problematic when the criminal sanction had been based on defamation.

At the same time, civil sanctions provide legal penalties for defamation by expression as well. In one case, compensation for damages was ordered when broadcast journalists criticized a sculptor by name. When this decision was challenged via a Constitutional Complaint, the Constitutional Court refused the order as being unconstitutional, and reasoned that such an order might create chilling effects, due to the threat of sanctions. ${ }^{49}$

BVerfGE 111, 147 Although the first case presented justified regulations on the assembly of neo-Nazis, another case was presented where the Court declared it unconstitutional to limit the activities of neo-Nazis, after a Constitutional Complaint was brought against refusing the right of neo-Nazis to assemble.

The ordinary courts found the grounds for prohibition of the assembly in Article 130, Section 1, Sentence 1 of the Penal Code. Although this article does not explicitly describe damage to "public order" as a condition for prohibition, the ordinary court's view was that damage to "public order" could be grounds for an unwritten rule for that prohibition. However, the Constitutional Court declared this decision to be unconstitutional, because such unwritten standards could not be sufficient grounds for a prohibition. ${ }^{50}$

Conclusions: The Jurisprudence of the Constitutional Court on Regulations on

Freedom of Speech As already mentioned, the Auschwitz lie case regarded a regulation to be constitutional even when it was based on expressed content. On the other hand, Lüth illustrated the importance of the freedom to freely express opinions. Moreover, the chilling effects of legal sanctions were mentioned in some decisions. In addition, a regulation on an anti-Jewish assembly was refused as being unconstitutional, since unwritten rules had been used, despite an explicit provision being in place. What is more, the Auschwitz lie case regarded the planned statements of opinion as not having a low value. In this case, protecting the name of Jews in Germany was especially necessary, and it was an exceptional case in which freedom of communication conflicted with very important interests.

It is certainly difficult to imagine judgments declaring a judicial decision as being unconstitutional in Japan. Furthermore, Japanese constitutional issues have

\footnotetext{
${ }^{48}$ BVerfGE 43, 130.

${ }^{49}$ BVerfGE 54, $129<139>$.

${ }^{50} \mathrm{BVerfGE} 111,147<156>$.
} 
often been argued as legal matters under ordinary laws. Therefore, it might be unfair to assert that the Japanese courts do not protect freedom of speech. Nonetheless, the German Constitutional Court has often declared a challenged administrative order to be unconstitutional. This approach of the German Constitutional Court seems to be different from the approach taken by the Japanese Court.

\subsubsection{Freedom of the Press}

In the decisions of the Constitutional Court, the right to freely express opinions, thus, has often been estimated to be significant and, therefore, regulations of that right have frequently been refused as unconstitutional. At the same time, as already suggested, German state press ordinances provide a public mission for the media, which could lead to the observation that regulating freedom of the press is easily justified. Below, the issue of how the German Constitutional Court involves the constitutionality of the regulations on freedom of the press is examined.

Firstly, there was a case dealing with the problem of an employer's harsh criticism of the workers' council in a company paper published by the employer. ${ }^{51}$ The ordinary courts forbade the uttering of such an expression, but the Constitutional Court held that a company's publication enjoyed the protection of freedom of the press, and it declared the prohibition to be unconstitutional. It was characteristic of the Constitutional Court to adopt a "broad and formal concept of the press" in including a company publication as being part of "the press." In addition, the judgement stressed the institutional understanding of freedom of the press and the importance of communication. Moreover, in this case, the anonymity of the contributors was upheld, also as a result of the institutional concept of the press.

The other case deals with state agents' searching the editorial office of Cicero magazine, because it was suspected of receiving leaked national secrets. The Constitutional Court rejected this government act as being unconstitutional, because its objective was to find informants. The Constitutional Court explained that Article 5 , Section 1, Sentence 2 of the Basic Law was of objective legal importance, and it argued that the institutional independence of publishing or broadcasting was guaranteed by this objective legal significance. It added that protection was necessary for such interests as keeping secret the identity of information sources, or maintaining trust between the press or broadcasting organizations and informants. Moreover, the Constitutional Court mentioned the possibility of the searching of an editorial office as having chilling effects on the press. ${ }^{52}$

What is more, in "Benetton Shock Advance II,"53 the question was asked as to whether advertising material that had a strong impact on readers should be

\footnotetext{
${ }^{51}$ BVerfGE 95, 28.

${ }^{52}$ BVerfGE $117,244<258 f$. $>$.

${ }^{53}$ BVerfGE 107, 275.
} 
permitted. The ordinary court decided the advertisement should be prohibited, to prevent unfair competition. In contrast, the Constitutional Court declared this prohibition to be unconstitutional. The judicial constitutional decision interpreted this case as being a matter of freedom of the press, and mentioned at the same time that the opinions expressed at that time were important for liberal and democratic national order. Moreover, a similar significance was noted in relation to the freedom to freely express opinions.

I have already noted that in Germany each state has an article that assigns a public mission to the press. Although some Japanese scholars have criticized such missions, because they result in various obligations, most concrete obligations are specifically and independently provided separately from a public mission. Even when the press is often required to protect "inner freedom," there is no express article requiring this protection. Therefore, a notice of the decisions concerning the protection of inner freedom might clarify the consequences of state press ordinances. There is a case in which the publisher of a press company did not inform the workers' council when the publisher dismissed an editor. ${ }^{54}$ When the publisher must inform such organizations, the competence of such a publisher would be restricted. The Constitutional Court concluded that this case was not related to freedom of the press. As its reason, the judge noted that the conflict arose between the publisher and the workers' council, not between the publisher and the journalists.

As suggested, in Germany, press ordinances articulate the public mission of the press, and it is required to protect inner freedom. Such a situation might imply rigid regulations on the press or on the competence of the publisher, however it has also been shown that the decisions of the Constitutional Court guarantee freedom of the press relatively strictly. Even though it does not apply to all cases, the institutional freedom of the press or its objective legal aspect has often functioned to eliminate the disadvantages of the press. The Constitutional Court, thus, permits not only limitations to the competencies of publishers, but, at the same time, has limited inner freedom to matters between publishers and journalists within a narrowly applied range. Therefore, inner freedom has not played a roll of severely limiting press freedom.

\subsection{German Popular Descriptions Concerning Freedom of Speech ${ }^{55}$}

Most German scholars seem to favor such decisions. Along with the Constitutional Court, they recognize the importance of the right to freely express opinions. This right is regarded not only as a private value, but also an element of political

\footnotetext{
${ }^{54}$ BVerfGE 52, 283.

${ }^{55}$ Schulze-Fielitz, supra note 43, p. 636.
} 
publications in democratic and constitutional nations. On the one hand, Article 5, Section 1 of the Basic Law is deemed to be rooted in human dignity, and the right to freely express opinions is held to satisfy, individually and publicly, such interests as mental curiosity, the thirst for knowledge, and the desire for participation. Furthermore, the right to freely express opinions is thought to contain an objective guarantee. In this view, the democratic public is regarded as the central institution for controlling government acts, which is related to the significance of the right to freely express opinions. In addition, the "interaction theory" is referred to as the doctrine necessary for consideration of the constitutionality of regulations on freedom of communication. ${ }^{56}$ Moreover, German lawyers have described how this significance has been noted in precedents dealing with balancing the public interest, and that the proportionality of burdens should be strictly reviewed in considering their justifications when freedom to communicate is regulated on the basis of content. $^{57}$

Furthermore, in relation to freedom of the press, institutional freedom and the public mission of the press is also mentioned by constitutional scholars. Likewise, practicing lawyers hold that the public mission, with regard to guaranteeing the proper logic (Eigenlogik) of the media, should bind the legislators, despite their intention to organize the institution of the press. ${ }^{58}$ German constitutional academics also explain inner freedom as a radiating effect emerging from freedom of the press into labor law. ${ }^{59}$ Although inner freedom would be applied in cases where there is a conflict between journalists and editors or publishers, such journalists, in this view, can claim merely minimal independence. ${ }^{60}$ According to that view, even when legislators create an institutional guarantee by enacting ordinances, their dispositions should also be limited.

\subsection{Considerations}

Although many Japanese scholars refer to arguments in the United States, there has been no Japanese judicial decision declaring the unconstitutionality of regulations on freedom of speech. At the same time, despite skeptical views with reference to the German approach, German judgements and scholars never disrespect freedom of speech, as has been demonstrated above.

\footnotetext{
${ }^{56}$ Ibid., p. 687.

${ }^{57}$ BVerfGE 124,300 concluded it was constitutional to prohibit an assembly admiring the Nazi leaders. But the Constitutional Court noted that statutes could be permissible only under strict neutral and equal conditions, if those laws ban and penalize infringements in relation to the contents of expressed opinions.

${ }^{58}$ Schulze-Fielitz, supra note 43, p. 707.

${ }^{59}$ Ibid., p. 745.

${ }^{60}$ Such independence of journalists is sometimes understood as a "declaratory Regulation." see Kloepfer (2010), p. 276.
} 
In discussions or decisions concerning the freedom of communication in Germany, certainly some particular aspects are raised. The regulation of any justification of Nazi rule is justified. Furthermore, even when strict proof is required for content-based regulations, there are cases in which such restrictions have been declared constitutional. Nonetheless, only factual-evidently untrue - assertions are held to lie outside the range of the right to freely express opinions, and the justification for content-based regulation of opinions is based on the fate of the Jews who have lived in Germany. In other words, it is exceptional to regulate speech. What is disallowed at most, for the purpose of safeguarding Jews in Germany, is justifications of the Nazi regime, and other decisions point to the chilling effects that result from legal penalties imposed on opinion makers without express legal rules, or, as has often been suggested, the right to freely express opinions is of constitutional significance in a liberal and democratic nation. In fact, the Constitutional Court has often regarded regulations on freedom of speech as unconstitutional. In this practice, it is different from the Japanese courts. Constitutional scholars favor such decisions by the Constitutional Court, and note the link between the freedom to freely express opinions and democratic procedures. Furthermore, academics require a strict review of the constitutionality of its regulation and German judicial decisions. In particular, content-based regulations on expressions are understood to be subject to the strict application of the proportionality test, which indicates its similarities to the views of Japanese authors.

In relation to freedom of the press, state press ordinances contain regulations on the public mission of the press. Despite having its Japanese critics, other regulations independently provide, for example, the right to make statements countering factual assertions by the media as an obligation. Despite the lack of explicit provision, inner freedom results not directly from the public mission of the press, but as a radiating effect arising from the freedom of the press on labor law. ${ }^{61}$ In jurisprudence, the range of inner freedom is shaped narrowly, and the Constitutional Court has held the dismissing of an editor not to be a matter of freedom of the press. Observers understand it merely as being indicative of the independence of journalists from editors. Although legislators have attempted to realize and ensure the responsibilities of the mass media in the form of inner freedom by enacting legislation, their power should be restricted. Moreover, freedom of the press is understood broadly as a guaranteed interest, and company publications are regarded as being part of the press. In addition, protection under freedom of the press has such requirements as safeguarding the anonymity of contributors to newspapers, protecting advertisements of materials with a strong impact, and offering protection against having the state search for informants. Therefore, despite German arguments about the institutional freedom of the press or its objective aspects, and despite provisions in state press ordinances involving the public mission of the press, press activities face few restrictions.

\footnotetext{
${ }^{61}$ In Japan, this idea is found also in the so-called "indirect effect theory."
} 
With regard to the three questions presented above (4.1), firstly, in Germany, freedom of speech is not exclusively related to human dignity. Secondly, also in Germany, in practice and theory this freedom is thought to be especially important. Although this report has pointed out only some of the doctrines or decisions dealing with freedom of communication, ${ }^{62}$ it would be an overstatement to maintain the view, which is often found in Japan, that in Germany no special thought is given to protecting freedom of speech. Such an argument does not hold up, which is the answer to the third question.

\section{Closing Remarks}

In the context of Japan's recent dramatic decrease in WPFI ranking, this report has discussed freedom of reporting or speech as a "human rights issue in Japan." Its conclusions can be divided into two parts. The first is that the issue of freedom of speech is not only a temporary issue in Japan. Beyond the legal restrictions on freedom of speech, unofficial limitations have also existed since the prewar era. On the other hand, although Japanese scholars have referred to discussions in the United States, there has been no judgement describing infringements on freedom of speech as unconstitutional. Consequently, it might also be reasonable to refer to theories in countries other than the United States, such as Germany for example, though some Japanese scholars seem skeptical of German doctrines involving freedom of speech. However, freedom of speech is relatively strongly guaranteed in Germany, which is this article's second conclusion. In addition, the German Constitutional Complaint procedure has some similarities to the Japanese incidental judicial constitutional review. Therefore, it is difficult to conclude that the strength of protection for freedom of speech depends on the existence of a constitutional court.

I took note of the WPFI's findings. However, the RWB is only an NGO, and, therefore, lacks the elements needed to determine freedom of the press rankings effectively. Nonetheless, it seems significant to reconsider Japan's present circumstances regarding the guarantee of freedom of speech on the occasion of such a ranking. This article has compared Japan's situation with that of Germany. In referring to the arguments presented above with reference to Germany, it would be more appropriate to focus on the differences between Japan and Germany than to emphasize differences between the United States and Germany, and it also seems to be important to take note of other countries' achievements, not only those of the United States, but also those of Germany and the other EU member states, where freedom of speech has been guaranteed more strongly than in Japan. It is also important that we investigate how this freedom is protected in those countries.

\footnotetext{
${ }^{62}$ Kloepfer, supra note 60 , p. 305 writes that the Constitutional Court has not decided concerning the matter of "pornographic artwork." Moreover, with regard to German different ways to controls "harmful books," see BVerfGE 83, 130 and 90, 1. In addition, in Germany, there is no specifical provision to regulate election campaigns.
} 


\section{References}

Ashibe N (supplanted by Takahashi K.) (2015) Kenpou Dai 6 Han (Constitutional law 6th edn.). Iwanamishoten, Tokyo

Fallon RH (2013) The dynamic constitution, 2nd edn. Cambridge University Press, New York

Jitsuhara T (2013) Hogoryouiki no Kakuchou to Saibansho no Kengen (The extends protected area and judicial competences). In: Hatajiri T, Tonami K (eds) Kenpou no Kihanryoku to Kenpou Saiban Kouza Kenpou no Kihanryoku Dai 2 Kan (Norm-craft of constitutional law and constitutional case lectures on norm-craft of constitutional law vol 2. Sinzansha, Tokyo, pp 141-157

Jouanjan O (2009) Freedom of expression in the federal republic of Germany. Indiana Law J $84: 867-883$

Kloepfer M (2010) Verfassungsrecht Band II. Verlag C. H. Beck, München

Matsui S (2010) Law in context Kenpou (Law in context the constitutional law). Yuhikaku, Tokyo Matsui S (2013) Masu-Media-Hou Nyuumon Dai 5 Han (Mass media law guide, 5th edn. Nihonhyouronsha, Tokyo

Mouri T (2008) Hyougen no Jiyuu - Sono Koukyousei to Morosa ni tsuite (Freedom of speechits publicness and weakness). Iwanamishoten, Tokyo

Sato K (2011) Nihonkokukenpou-Ron (Theory of the Japanese constitutional law). Seibundo, Tokyo

Schulze-Fielitz H (2013) In: Dreier H (ed) Grundgesetz Kommentar, Bd. I, 3rd edn. Mohr Siebeck, Tübingen, pp 621-750

Sogabe M, Akasaka K, Arai M, Ogata T (eds) (2012) Kenpou-Ronten-Kyoushitsu (Lectures involving issues of the constitutional law). Nihonhyouronsha, Tokyo

Suzuki H, Yamada K (eds) (2011) Yoku Wakaru Media-Hou (Good understanding media law). Minervashobo, Kyoto

Suzuki H (2016a) Housou-Jigyousha no Hyougen-no-Jiyuu to Sityousha no Shiru-Kenri (Freedom of speech of broadcasting companies and freedom of knowledge of viewers). Hougaku Semin $738: 24-28$

Suzuki H (2016b) "Houdou-no-Jiyuudo-Ranking" wo kangaeru "Kokkyo-naki-Ishidan" no Chousa kara kangaeru kakosaitei no "72i" no Haikei to Mondaiten (Thinking about "World Press Freedom Index". Its backgrounds and issues in the view of the research of "Reporters Without Borders"). Journalism 314:106-112

Tonami K (2015) Judicial review in Japan and its problems. Waseda Bull Comp Law 33:1-11

Watanabe Y, Shishido G, Matsumoto K, Kudo T (2016) Kenpou I Kihonken (The constitutional law I fundamental rights). Nihonhyouronsha, Tokyo

Yamada K (2010) Hou to Journalism Dai 2 Han (Law and journalism, 2nd edn. Gakuyoushobou, Tokyo

Yamakawa Y (1987 (reprinted in 2012)) Riekikouryou-Ron (Theory of balancing). In: Nobuyoshi A (ed) Kouza Kenpou-Soshou Dai-2-Kan (Lectures on constitutional procedure 2nd band). Yuhikaku, Tokyo, pp 301-345

\section{Author Biography}

Takashi Jitsuhara assistant professor of Constitutional Law and Information Law, Faculty of Law at the Fukuoka University, Japan. He studied law in Chiba from 1994 to 1998. After his studying from 1998 to 2003 in Chiba (promoted in 2000) and Waseda (Tokyo), he was, first, lecturer at Nagasaki-Kokusai University from 2004 to 2009 and Nagasaki-Kenritsu University from 2009 to 2016. Since 2016, he is Assistant Professor of Constitutional Law and Information 
Law, Faculty of Law at the Fukuoka University. In 2011 (Apr.-Sep.), he had been a guest research fellow at Munich University. He is a member of Japan Public Law Association, Japan Constitutional Law Association, Constitutional Theory Association, Association for German Constitutional Law, Constitutional Law Association Kyushu and Information Network Law Association Japan. Among his publications are monographs; Internet Society and The Right to be forgotten (Gendaijimbunsha, 2015), Constitutional Normpower and Media Law (Sinzansha, 2015), 100 Constitutional Law Precedents (Yuhikaku, 2013), Constitutional Normpower and Constitutional Cases (Shinzansha, 2015), Good understood Media Law (Minervashobo, 2011), Liberty and Security-Theorie and Exercises in Coutries (Shogakusha, 2009), German Constitutional Precedents III (Shinzansha, 2008) and Constitutional Law for Beginners (Hokujusyuppan, 2008).

Open Access This chapter is licensed under the terms of the Creative Commons Attribution-NonCommercial-NoDerivatives 4.0 International License (http://creativecommons. org/licenses/by-nc-nd/4.0/), which permits any noncommercial use, sharing, distribution and reproduction in any medium or format, as long as you give appropriate credit to the original author (s) and the source, provide a link to the Creative Commons license and indicate if you modified the licensed material. You do not have permission under this license to share adapted material derived from this chapter or parts of it.

The images or other third party material in this chapter are included in the chapter's Creative Commons license, unless indicated otherwise in a credit line to the material. If material is not included in the chapter's Creative Commons license and your intended use is not permitted by statutory regulation or exceeds the permitted use, you will need to obtain permission directly from the copyright holder.

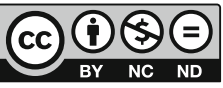

